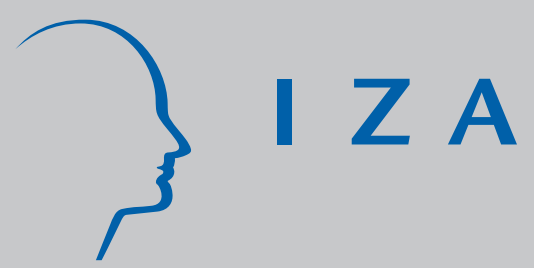

IZA DP No. 665

Fancy a Stay at the „Hotel California“?

Foreign Direct Investment, Taxation and Firing Costs

Holger Görg

December 2002 


\title{
Fancy a Stay at the "Hotel California"? Foreign Direct Investment, Taxation and Firing Costs
}

\author{
Holger Görg \\ University of Nottingham \\ and IZA Bonn
}

Discussion Paper No. 665

December 2002

\author{
IZA \\ P.O. Box 7240 \\ D-53072 Bonn \\ Germany \\ Tel.: +49-228-3894-0 \\ Fax: +49-228-3894-210 \\ Email: iza@iza.org
}

This Discussion Paper is issued within the framework of IZA's research area Internationalization of Labor Markets. Any opinions expressed here are those of the author(s) and not those of the institute. Research disseminated by IZA may include views on policy, but the institute itself takes no institutional policy positions.

The Institute for the Study of Labor (IZA) in Bonn is a local and virtual international research center and a place of communication between science, politics and business. IZA is an independent, nonprofit limited liability company (Gesellschaft mit beschränkter Haftung) supported by the Deutsche Post AG. The center is associated with the University of Bonn and offers a stimulating research environment through its research networks, research support, and visitors and doctoral programs. IZA engages in (i) original and internationally competitive research in all fields of labor economics, (ii) development of policy concepts, and (iii) dissemination of research results and concepts to the interested public. The current research program deals with (1) mobility and flexibility of labor, (2) internationalization of labor markets, (3) welfare state and labor market, (4) labor markets in transition countries, (5) the future of labor, (6) evaluation of labor market policies and projects and (7) general labor economics.

IZA Discussion Papers often represent preliminary work and are circulated to encourage discussion. Citation of such a paper should account for its provisional character. A revised version may be available on the IZA website (www.iza.org) or directly from the author. 
IZA Discussion Paper No. 665

December 2002

\section{ABSTRACT \\ Fancy a Stay at the "Hotel California"? Foreign Direct Investment, Taxation and Firing Costs*}

This paper looks at the trade off between investment incentives and exit costs for the location of foreign direct investment (FDI). This issue does not appear to have been tackled in much detail in the literature. The analysis considers the effect of profit taxation (as a measure of investment incentives) and an index of hiring and firing costs (proxying exit costs) on the location of US outward FDI in 33 host countries. The results suggest that US FDI, in particular in manufacturing is negatively affected by the level of profit taxation and exit costs. Hence, if countries want to attract FDI it may not suffice that incentives are provided in order to ease the entry of multinationals. Instead, it also appears to be important that exit costs are at a level attractive to multinationals. In other words, multinationals may not check into an attractive looking Hotel California type host country if it is difficult to leave.

JEL Classification: F23, H25, J65

Keywords: foreign direct investment, exit costs, firing costs, investment incentives, taxation

Holger Görg

School of Economics

University of Nottingham

Nottingham NG7 2RD

UK

Tel.: $+44(0) 1158466393$

Fax: +44 (0) 1159514159

Email: holger.gorg@nottingham.ac.uk

\footnotetext{
${ }^{*}$ An earlier version of this paper was presented at the DNB $5^{\text {th }}$ Annual Conference in Amsterdam. I am grateful to Tamim Bayoumi, Spiros Bougheas, David Greenaway, Aoife Hanley, Wolfgang Keller, Peter Neary, Franz Palm, Ard den Reijer, Eric Strobl, Wim Suyker, Alan Taylor and lan Wooton for helpful comments and suggestions. I would especially like to thank Jack Mutti for kindly sending me unpublished data on effective tax rates and Katy Wakelin for making the firing cost data available to me. All remaining errors are, of course, my own. Financial support from the Leverhulme Trust (Programme Grant F114/BF) is gratefully acknowledged.
} 


\section{Introduction}

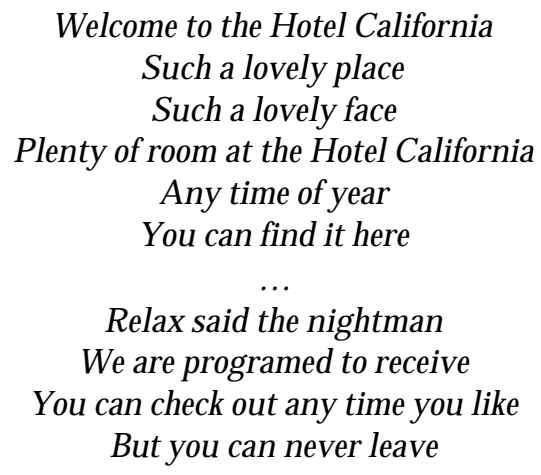

Hotel California (TheEagles, 1976)

The lyrics of the song Hotel California, released by The Eagles in 1976 contain an interesting insight for economists. In economists' speech we could think of Hotel California as offering low entry costs giving an incentive to enter, but there being (in that particular case arguably very!) high exit costs. What has all of that got to do with economics? It can be seen as providing an interesting analogy within which to think of the location decisions of multinational firms (MNFs).

It is well known that many host country governments around the globe attempt to attract multinationals by offering generous investment incentives. For example, Head (1998) reports that the government of Alabama paid the equivalent of $\$ 150,000$ per employee to Mercedes for locating its new plant in the state in 1994. Across the Atlantic, the British Government provided the equivalent of an estimated $\$ 30,000$ and $\$ 50,000$ per employee to attract Samsung and Siemens respectively to the North East of England in the late 1990s (Girma et al., 2001). Corporate tax rates are also used actively as a policy tool to attract 
MNCs. A prominent example among developed countries is the Republic of Ireland which offers a nominal tax rate of 10 percent on corporate profits. ${ }^{1}$

The use of investment incentives has been discussed in the recent theoretical literature (e.g., Haaland and Wooton, 1999, Haufler and Wooton, 1999, Kind et al., 2000), one of the conclusions being that incentives may lead to competition between host country governments which may erode any potential benefits from FDI. Empirical evidence on whether incentives (grants or tax incentives) may be able to attract the location of multinationals has also been recently provided in a number of papers. For example, Hines (1996) and Head et al. (1999) look at the impact of tax rates and investment incentives, respectively, on multinationals investing in the US. Hubert and Pain (2002) study how FDI in EU countries responds to investment incentives offered by host countries. Desai et al. (2002), Grubert and Mutti (2000) and Devereux and Griffith (1998) examine the effects of tax rates on location decisions of US companies investing abroad. These studies generally find that both tax rates and investment incentives have an impact on location decisions of multinationals. $^{2}$

While this may suggest that an appealing looking Hotel California type host country may be able to lure in multinationals, the issue of exit costs appears to have received far less attention in the literature to-date. This may be an important issue, however, if multinationals, which are often argued to be highly footloose (Flamm, 1984; Görg and Strobl, 2002) care about the potential costs they have to incur when eaving the host country. In particular, costs due to employment protection legislation, hiring and firing restrictions, lay-off payments,

\footnotetext{
${ }^{1}$ Grubert and Mutti (2000) calculate that the effective tax rate accruing to US multinationals in Ireland was around 3 percent in 1990.

${ }^{2}$ However, Head et al. (1999) in their study of Japanese investment in the US argue that competition between host (state) governments to attract FDI may render investment subsidies ineffective as they offset each other.
} 
severance pays, etc. may be regarded as being important. ${ }^{3}$ Without uncertainty about the timing of exit this may be just another fixed or variable cost which can be factored in with certainty when calculating the expected net present value of the investment. It becomes more complicated when there is uncertainty about exit, however.

Two recent related papers by Haaland et al. (2002) and Haaland and Wooton (2002) consider theoretically both the importance of investment incentives and exit costs for the decisions of multinational firms to invest greenfield in a host country. They build partial equilibrium models in which a foreign monopolist bases its location decision on the net present value of its future operations, which is influenced by operating profits, government subsidies and exit costs. The latter have a role in these models because there is an exogenously given industry specific uncertainty that the industry may collapse in future. In these models there is a trade off between subsidies and exit costs. The latter may discourage the location of multinationals particularly in industries with high risk of failure as these industries care more about potential exit costs. ${ }^{4}$

As far as we are aware, the idea of the trade-off between entry and exit costs for the location of multinationals has not been put to the data yet. ${ }^{5}$ This is the main aim and innovation of this paper. The empirical analysis uses data on outward foreign direct

\footnotetext{
${ }^{3}$ The issue of employment protection legislation has been discussed in the labour economics literature; see, for example, Lazear (1990) and Jackman et al. (1996).

${ }^{4}$ Dewit et al. (2002) challenge this view on the importance of exit costs by allowing for strategic behaviour between the foreign entrant and an existing host country firm. In their model, firing costs do not necessarily deter the entry of the foreign firm (depending on the nature of competition). They do not consider the effect of investment incentives, however. Also, only greenfield investment by MNFs is considered.

${ }^{5}$ As pointed out above, a number of empirical papers look at the significance of investment incentives such as grants or taxes for the location of FDI. Haaland et al. (2002) present an empirical analysis relating FDI to exit costs (proxied by the level of labour turnover rates), but do not consider investment incentives. There is also a related literature looking at the effects of political and civil rights variables on FDI (Schneider and Frey, 1985).
} 
investment (FDI) stocks by the US. ${ }^{6}$ US outward FDI is related to the effective corporate tax rate faced by US multinationals in the host country, and an index of firing costs. The tax rate is seen as a proxy for the inducements to entry for the multinationals. ${ }^{7}$ The latter variable is taken as a proxy for exit costs. To the best of our knowledge, such a variable has not been used in previous empirical studies on the location of FDI.

The empirical model is embedded in a theoretical framework based on Dixit's (1989) work on entry and exit under uncertainty, rather than relying on the models by Haaland et al. (2002) and Haaland and Wooton (2002). Those models relate specifically to new greenfield investments by multinationals as, by definition, there is no takeover possible due to the MNF being a monopolist. Also, they do not allow for changes in the behaviour of multinationals already located in the host country following changes in entry or exit costs. The Dixit framework does not necessitate a specific focus on greenfield investment, but one can also think of firms entering by taking over an existing domestic or foreign firm (as long as there is a sunk cost of entry), and existing multinationals expanding in the host country via new investments, or exiting the host country. In that sense, the model appears more appropriate for our data, which cover FDI by new greenfield or acquisitions, as well as investments by parent companies in foreign affiliates already located in the host country. ${ }^{8}$

The estimation results show that firing costs and taxation matter for the location of US FDI. This is particularly the case in manufacturing (but not services) industries and is robust to a number of alternative estimation specifications. The finding on the importance of taxation

\footnotetext{
${ }^{6}$ The choice of the US is motivated by two factors. First, the US is by far the largest outward investor in the world; see, for example, the recent discussion by Lipsey (2001). Second, data on US outward investment are easily available.

${ }^{7}$ The focus on the tax rate of course leaves aside other firm- or industry-specific incentives that may be offered by potential host countries. This is due to data availability. Under the assumption that these are complements of tax breaks, i.e., are positively correlated, this should not cause a problem in the empirical estimation.
} 
for the location of FDI is in line with other recent evidence provided by, e.g., Hines (1996), Grubert and Mutti (2000) and Desai et al. (2002). The significance of exit costs, however, suggests a further important, yet heretofore neglected conclusion: multinationals, in particular in manufacturing industries, do not only care about entry costs, but also about ease of exiting the host country.

The remainder of the paper is structured as follows. Section 2 presents a simple theoretical framework to motivate the empirical analysis. Section 3 presents and describes the data. Section 4 discusses the econometric methodology and results. Section 5 concludes.

\section{Theoretical frame work}

To motivate our empirical analysis below this section sets out a brief simple theoretical framework based on Dixit's (1989) model on investment under uncertainty. ${ }^{9}$ Dixit showed that the entry and exit decision of a firm under uncertainty can be analysed using an analogy borrowed from options pricing theory. In Dixit's model, a firm at any given time has an option to enter a host country if it had not been operating there already, exit the market if it was operating, or stay put, wait for another period and then decide. The level of entry and exit costs play crucial roles in a firm's decision about which option to take. Specifically, Dixit shows in his model that as the level of exit costs increases, firms deciding whether or not to enter are more likely to stay out of the market.

It is worth illustrating in a bit more detail how one arrives at that conclusion. Assume that a foreign firm enters a market by committing a lump sum $h$ which one can think of as the

\footnotetext{
${ }^{8}$ Also, the Dixit model does not rely on an exogenously given uncertainty but the uncertainty is explicitly modelled.

${ }^{9}$ Campa's (1993) theoretical framework for his analysis of the impact on FDI of uncertainty about exchange rates is also based on Dixit's model. Tybout and Roberts (1997) model of entry and exit in exporting with sunk costs is also related.
} 
sunk cost of entry. A host country government may try to foster entry by offering investment incentives $g$ which are aimed at reducing the sunk cost of entry. Hence, net entry costs equal $s$ $=h-g>0 .{ }^{10}$ While producing, a firm faces variable cost $c$. Upon exit, there is an exit cost $k$ which one can think of as severance payments, compliance with firing restrictions, etc. After exiting, a firm would have to incur again $s$ if it decided to re-enter at a later stage. A firm maximises its expected net present value given a depreciation rate of $\delta$. There is uncertainty in the firm's decision due to fluctuations of the market price $P$ which follows some stochastic process. $^{11}$

One can interpret the entry of a firm as exercising an option to invest, the exercise price being equal to the sunk cost of investment $s$. Similarly, exit is an option to divest with option price $k$. In this scenario, there are two decision variables $P_{e n}$ and $P_{e x}$. If the market price $P$ rises above $P_{e n}$ it is beneficial for the firm to exercise the option and enter, while a firm should exit if $P$ falls below $P_{e x}$. At any given time the firm can be in two possible states, either active in the host country (1) or not (0).

In the latter state, the firm decides whether to remain inactive or enter; it will do so if $P_{\text {en }}$ satisfies the value matching condition ${ }^{12}$

$$
V_{0}\left(P_{e n}\right)=V_{l}\left(P_{e n}\right)-s
$$

where $V_{0}(P)$ is the net present value of starting with $P$ in the inactive state and following optimal policies, and similarly for $V_{l}(P)$ in the active state. That is, the firm would

\footnotetext{
${ }^{10}$ For example, the UK and Ireland offer investment subsidies which are paid as a percentage of capital investment at entry or as a percentage of employment. The latter may at least be partly sunk costs if one views labour as a quasi-fixed factor as in Oi (1962). Also, tax incentives may be thought of as being aimed at reducing sunk capital costs.

${ }^{11}$ Dixit (1989) assumes it follows a Brownian motion but also shows that other types of fluctuations, e.g., mean reverting process produces similar results.

12 Strictly speaking, $P_{e n}$ must also satisfy a smooth pasting condition, see Dixit (1989, p. 627).
} 
enter if the present value from entering minus the cost of entry is at least equal to the present value from staying out. ${ }^{13}$

If the firm is already active in the host country it decides whether to continue to stay in or exit. This, in turn, depends on the present value from staying in compared to the present value from exiting minus the exit cost,

$$
V_{l}\left(P_{e x}\right)=V_{0}\left(P_{e x}\right)-k
$$

$V_{l}(P)$ is shown to depend negatively on the level of variable production costs and uncertainty about the output price.

Totally differentiating the explicit functional forms of the above two equations, one can show that as $s$ or $k$ increase, $P_{e x}$ decreases and $P_{e n}$ increases. Hence, increases in exit cost or reductions in investment incentives (for constant levels of sunk entry cost) widen the band of inaction, where firms find it neither optimal to enter if they are inactive, or exit if they are active.

Based on this simply sketched theoretical framework one can derive the hypothesis that reductions in investment incentives (i.e., lower grants or higher taxes) which increase sunk entry costs and/or increases in exit costs may be expected to reduce the level of foreign direct investment in a host country. This is due to lower entry of new foreign affiliates, since the threshold price for entry increases, and the lack of new investment by foreign firms already located in the host country, as they find it optimal to remain as they are. In the following sections we set out to test this hypothesis empirically.

\footnotetext{
${ }^{13}$ In that case, the return to the firm is the expected capital gain accruing on the asset held for future investment.
} 


\section{Description of the data}

In order to check whether there is empirical support for the above hypothesis one would ideally like to analyse firm or plant level data on entry and exit decisions and investment behaviour of multinationals. One would then relate these to corresponding micro data on tax payments, subsidies and exit costs. However, such data are not available to the researcher. The analysis in this paper uses country level data instead and relates the level of US FDI in host countries to the level of taxation and exit costs at the country level. ${ }^{14}$ There are, of course limitations in applying country level data to an essentially firm level question. However, we feel that in the absence of more appropriate data this analysis can provide at least a first feel as to whether or not the theoretical issues are borne out by the empirical evidence.

The empirical analysis uses data on the stock of outward foreign direct investment by US multinational firms in 33 host countries around the globe. A list of host countries is given in Table 1. The US FDI data are available from the 1970s onwards from the Bureau of Economic Analysis (BEA) at the US Department of Commerce. ${ }^{15}$ They allow us to distinguish total FDI, FDI in manufacturing and in services industries. ${ }^{16}$ This broad classification allows one to test whether manufacturing and services respond differently to taxation and exit costs. One may expect such differences for a number of reasons. First, there may be different levels of uncertainty in the two broad sectors. This has been illustrated vividly by the recent troubles experienced by such high profile service activities as "the new economy", pension funds, accounting and consulting services etc. while manufacturing firms have not been hit that hard. Second, it may be possible that fixed (sunk) costs differ across industries, with manufacturing

\footnotetext{
${ }^{14}$ As pointed out above, only taxes are considered as investment incentives, mainly due to data constraints.

${ }^{15}$ Nominal values are deflated and expressed in 1995 US\$ using a GDP deflator.

${ }^{16}$ Note that manufacturing and services do not add up to total but that there is a residual category including mostly FDI in natural resources.
} 
activities being more likely to be relatively intensive in physical capital and services in labour utilization. Therefore, sunk costs may be relatively more important for manufacturing industries, which may impact on firms' relative attitudes towards incentives and exit costs as suggested by the theoretical framework. Specifically, if sunk costs are less important in services, FDI in that sector may be less responsive to changes in investment incentives and exit costs, as the band of inactivity is narrower than for manufacturing FDI.

The level of US FDI stocks is related to measures of profit taxation and exit costs affecting multinationals. Taxation is measured using data for effective tax rates for US multinationals available from Grubert and Mutti (2000). They use US corporate income tax returns to calculate "[a]verage host country corporate tax rates $[\ldots]$ by taking total income taxes paid by manufacturing CFCs [controlled foreign corporation] incorporated in that country divided by their total earnings and profits" (Grubert and Mutti, 2000, p. 830). While this is a measure calculated for manufacturing firms, there is no obvious reason why these rates should not be highly correlated with effective rates of taxation in service industries. Hence, the measure may be a valid proxy for the average tax rate even when considering FDI in services. The data published in Grubert and Mutti (2000) are for 1984, 1986, 1990 and 1992. John Mutti generously made available data for 1988, 1994 and 1996 also.

Exit costs are difficult to measure as they include a variety of components. In this paper exit costs are proxied using a country level index on the magnitude of hiring and firing costs in the country. The index itself, which does not appear to have been used in the literature thus far, is constructed based on extensive surveys of managers conducted by the World Economic Forum. In the survey, participants are asked to give a score between 0 and 1 in response to a number of questions describing the overall business climate and competitiveness 
of the country in which the firm operates. The particular question for the index used here is: "Hiring and firing practices are too restricted by government or are flexible enough". The higher the index the more business friendly do respondents judge these practices. The index is available to us from 1986 to 1996.

Combining the data from these different data sources yields a country panel dataset for US outward FDI for the years 1986, 1988, 1990, 1992, 1994 and 1996.

Table 1 shows some summary statistics on average levels of taxation and exit cost indices to provide an overview of the variation in the two variables across host countries. It is clear that the US, as the home country, has one of the most liberal hiring and firing practices, it is only surpassed by Hong Kong and Singapore. By contrast, EU countries, with the exception of the UK, score fairly low on this index; all of them have indices well below the overall sample mean. India appears to have the highest level of exit costs in the sample. The average effective rate of taxation is also fairly high among EU countries, although there is the obvious exception of Ireland. Japan is the country with the highest rate of taxation, however.

\section{[Table 1 here]}

As the figures reported in Table 2 show, most countries included in the sample increased their firing cost index (i.e., liberalised firing practices) and reduced their effective rate of taxation between 1986 and 1996. The most striking example is perhaps New Zealand, which increased its firing index by 45 decimal points, equivalent to an increase by 169 percent, and experienced a decrease in its effective tax rate by 33 decimal points (or 76 percent). However, there are also countries which seem to have reduced the flexibility of firing practices as indicated by a decrease in the index, such as India, Korea and, most notably from a European perspective, Italy. Furthermore, a number of countries increased their effective tax 
rate - for example, Singapore experienced an increase by 2 percentage points, equivalent to a 110 percent increase in the tax rate between 1986 and 1996. Ireland experienced an even higher increase in both absolute and percentage terms. However, in both cases, these represent increases from very low bases.

\section{[Table 2 here]}

As a first step in relating the data on taxation and exit cost indices to US outward FDI stocks, Figures 1 and 2 show the raw data on the relationship between the two variables and the level of FDI. In these figures, FDI is expressed as FDI stocks relative to total GDP to control for variations in country size. Both graphs present separate pictures for total FDI, manufacturing FDI and services FDI. While the observations are scattered around considerably, one may detect a somewhat positive relationship between the exit cost index and total FDI. In other words, the lower are exit costs, the higher is the stock of total FDI. This is in line with the first hypothesis advanced above, that FDI is negatively related with the level of exit costs. The figure also shows that this relationship does not appear as strong for manufacturing FDI. The scatter diagram for the rate of taxation and FDI may suggest a negative relationship, in particular for total and services FDI as shown in Figure 2.

\section{[Figures 1 and 2 here]}

However, these graphs cannot control for other contemporaneous factors impacting on FDI. In order to address this issue and, at least as importantly, to get an understanding of the quantitative relationship and trade-off between taxation and exit costs, the paper now turns to an econometric modelling of the determinants of US FDI stocks in the 33 host countries. 


\section{Econometric analysis}

The modelling approach followed in this paper is based on a gravity-model type equation. We hence assume that FDI is influenced positively by the economic "mass", i.e., market size of, and negatively by the distance between, home and host country. The use of such gravity equations for the analysis of capital transactions and, in particular, foreign direct investment has become widespread in the recent literature, recent examples being Mody et al. (2002), Portes et al. (2001) and Wei (2000).

In line with this strand of literature, the following is the basic empirical equation to be estimated

$$
\ln \left(F D I_{i t}\right)=\lambda_{1} \tau_{i t}+\lambda_{2} \kappa_{i t}+\lambda_{3} X_{i t}+v_{t}+\mu_{i}+\varepsilon_{i t}
$$

where FDI is US FDI stocks (in 1995 US \$) in host country $i$ at time $t, \tau$ is the effective average tax rate, $\kappa$ is the firing cost index, $v$ is a full set of time dummies. Given that the data form essentially a short country panel the empirical estimation allows for the presence of a time-invariant country specific effect $\mu$ which is estimated using random effects (RE) techniques. ${ }^{17}$ The remaining error term $\varepsilon$ is assumed to be white-noise.

The vector $X$ includes a number of other host country variables which may be expected to impact on FDI and which usually enter into gravity equations. Variables included are log GDP, log GDP per capita, log distance between home and host country and a dummy equal to one if the host country is English speaking. GDP and GDP per capita are included to control for differences in market size and purchasing power, although the latter variable may also be

\footnotetext{
${ }^{17} \mathrm{RE}$ is chosen because it is more efficient than the fixed effects estimator. Also, the 33 host countries do not cover all host countries for US FDI and, moreover, cover only a fraction of all FDI stocks in the world. In such a case, Baltagi (2001) argues that RE is appropriate. However, RE assumes that the country specific effect is not correlated with the right hand side variables; if that assumption is violated, RE is inconsistent. Hausman tests performed for all estimations, which are reported in the tables below, support the choice of the RE estimator.
} 
thought of as being a proxy for average labour cost in a model with labour being the only factor of production. The two GDP variables are in constant 1995 US \$ taken from the World Development Indicators. Distance is measured as the distance in kilometres between Washington DC and the host country capital city and is included as a rough proxy for investment cost, with costs increasing in distance. ${ }^{18}$ Hence, one would expect a negative sign on this variable. Finally, dummy equal to one if the host country's official language is English is included to allow for the fact that common cultural links or reductions in transaction costs due to a common language may impact positively on FDI flows between countries.

Equation (3) is estimated pooling the bi-annual data for 1986 to 1996 for all available host countries. Estimation results are presented in Table 3. Column (1) shows results for total FDI, (2) for manufacturing FDI and (3) for services FDI respectively. Overall, it is notable that the control variables all turn out as expected. GDP is positive and statistically significant at the one percent level, GDP per capita is always positive albeit only statistically significant in two cases, distance is consistently negative and the English speaking dummy is always positive and statistically significant.

Turning our attention to exit costs and taxation, it is clear from column (1) that both factors are important and have the anticipated effects. The results show that an increase in the exit cost index by one percentage point raises FDI by 0.79 percent. Similarly, a reduction in the tax rate by 1 percentage point increases FDI by 0.81 percent. Taking these point estimates at face value we can conduct simple thought experiments asking questions like: if a country wants to increase its tax rate but maintain its current level of FDI, by how much would it have to increase its exit cost index? In the example of column (1) if a country were to increase its tax rate by 5 percentage points it would have to achieve an increase in its exit cost index by 5.1

\footnotetext{
${ }^{18}$ Available at www.eiit.org.
} 
percentage points in order to maintain its value of inward US FDI stocks, all other things being equal. More specifically, if a country with a low tax rate but relatively high exit cost index, for example Ireland, were able to increase its exit cost index to the level of the US (i.e., by 21.8 percentage points from 0.490 to 0.708 ) it could afford to increase its effective rate of taxation by 21.3 percentage points and keep its level of US FDI stocks constant. ${ }^{19}$

The breakdown of total FDI into its manufacturing and services components brings with it some interesting insights. Comparison of the point estimates in columns (1) and (2) show that the marginal effects of exit costs and taxation appear larger for manufacturing than for total FDI. Compare this to the results in column (3) for services FDI, where both the exit cost index and taxation produce statistically insignificant coefficients. Hence, while there is support from these first regressions that exit costs and taxation matter for total and manufacturing US FDI there is no evidence that this is also the case for FDI in services sectors. This may suggest that sunk costs matter less for services industries and, hence, FDI in services is less responsive to changes in investment incentives and exit costs.

\section{[Table 3 here]}

The basic specification estimated in Table 3 constrains the effect of taxation and exit costs to be equal across countries. This may be a very stringent assumption. In particular, one may expect differences in the effects of these two variables on FDI across developed and developing countries. For example, it may be likely that degrees of uncertainty are different between these two groups of countries, with developing countries markets being more risky at least for manufacturing activities due to economic and political instabilities. ${ }^{20}$

\footnotetext{
${ }^{19} 0.789 *(0.708-0.490) / 0.807$

20 As argued above, services may be more uncertain in developed countries as illustrated by the troubles experienced recently by firms in financial and business services.
} 
In order to allow for this possibility we calculate a developing dummy $=1$ if the host country is a developing country. This dummy is then interacted with the exit cost index and the tax variable in order to allow the coefficients on these variables to differ for the two groups of countries. The results of these estimations are reported in Table 4. The first three columns show results for the definition of the dummy as being equal to 1 if the country is a low income country according to the World Bank classification. A different definition for the dummy is used in columns (4) to (6) where the dummy is one if the country is either a low income or a middle income country.

The table also reports the results of a Wald test for the joint significance of the interaction terms and the dummy variable. Note that we can reject the hypothesis that the coefficients are jointly equal to zero only for one specification, namely in column (3). The results show a very strong negative effect of the tax rate in low income countries which suggests that a one percentage point increase in the tax rate will lead to a reduction in US services FDI stocks by 12.1 percent. For developed countries, there is still no statistically significant effect of the tax rate, however, similar to the result in Table 3.

For the results in columns (1), (2) and (4) - (6), the Wald test suggests that the estimation results in Table 3 without interaction terms are preferred. Furthermore, in those cases the interaction terms in are individually not statistically significantly different from zero. Overall, it is reassuring to note, also, that the results in Table 4 are similar to those in Table 3 in terms of magnitude and statistical significance levels.

[Table 4 here] 
It was apparent from Tables 1 and 2 above that for a number of countries the firing cost indices were not available for the full period. $^{21}$ As we can therefore not observe all changes in this variable over time the inclusion of these countries may potentially bias the results. To check for any possible bias we re-estimated all above equations excluding countries for which we do not have observations on the exit cost index for the full period. The baseline regressions, constraining the effect of taxes and firing cost index to be the same across countries, are reported in Table 5. Note that the coefficients obtained are very similar, qualitatively and quantitatively, to the results in Table 3.

\section{[Table 5 here]}

A final alternative specification allows the coefficients to vary by country group, similar to the estimations in Table 4. These results, provided in Table 6 now suggest that the specifications in columns (2) and (3) be preferred to the equivalent ones in Table 5. In other words, the estimations suggest that the coefficients on both exit costs and taxation differ between low income countries on the one hand, and high and middle income countries on the other hand. In particular, for manufacturing FDI the effect of exit costs is much stronger for low income countries than for the other group, as indicated by the positive and statistically significant coefficient on the interaction term in column (2). The total point estimate for the effect of exit costs on US FDI in a low income country is now $0.929+5.696=6.625$, i.e., a one percentage point increase in the exit cost index (i.e., an improvement in firing restrictions) would lead to an increase of US FDI stocks in manufacturing by 6.6 percent, ceteris paribus. In column (3), none of the interaction terms are statistically significant individually, only the developing dummy on its own is.

\section{[Table 6 here]}

\footnotetext{
${ }^{21}$ Tax data were available for all countries for the full period.
} 


\section{Conclusion}

This paper looks at the trade off between investment incentives and exit costs for the location of foreign direct investment (FDI). While there has been some recent theoretical work investigating this issue, there does not appear to be any prior empirical work in this area. This paper attempts to fill this gap in the literature. The empirical analysis considers the effect of profit taxation (as a measure of investment incentives) and an index of hiring and firing costs (proxying exit costs) on the location of US outward FDI in 33 host countries.

The empirical results are as follows. US FDI is negatively affected by the level of profit taxation and firing costs. This relationship holds only for manufacturing FDI, not for services FDI. The results are robust to a number of different empirical specifications. There is only limited evidence that the effects of firing costs and taxation differ between developed and developing countries.

These results provide an important, yet heretofore neglected conclusion. If countries want to attract FDI, in particular in manufacturing, it may not suffice that incentives are provided in order to ease the entry of multinationals. Instead, it also appears to be important that exit costs are at a level attractive to MNFs. This includes, for example, such factors as redundancy payments, ease of firing of workers, etc. Of course, these are exactly the issues that are being debated as part of an allegedly necessary reform of European labour markets in general. The effect of FDI may provide another angle from which to look at the issue of reforming labour markets in order to remain competitive as a location for international production.

So what about Hotel California? It seems that just having a "lovely place" may not be enough to win new customers - if they are not allowed to leave easily whenever they like. 


\section{References}

Baltagi, B.H. (2001), Econometric analysis of panel data, $2^{\text {nd }}$ edition. New York: Wiley.

Campa, J.M. (1993), Entry by foreign firms in the United States under exchange rate uncertainty, Review of Economics and Statistics, Vol. 75, pp. 614-622.

Desai, M.A., C.F. Foley and J.R. Hines (2002), Chains of ownership, tax competition, and foreign direct investment, mimeo, Harvard University.

Devereux, M.P. and R. Griffith (1998), Taxes and the location of production: Evidence from a panel of US multinationals, Journal of Public Economics, Vol. 68, pp. 335-367.

Dewit, G., D. Leahy and C. Montagna (2002), Employment protection and foreign direct investment in dynamic oligopoly, mimeo, University College Dublin.

Dixit, A. (1989), Entry and exit decisions under uncertainty, Journal of Political Economy, Vol. 97, pp. 620-638.

Flamm, K. (1984), The volatility of offshore investment, Journal of Development Economics, Vol. 16, pp. 231-248.

Girma, S., D. Greenaway and K. Wakelin (2001), Who benefits from Foreign Direct Investment in the UK?, Scottish Journal of Political Economy, Vol. 48, pp. 119-133.

Görg, H. and E. Strobl (2002), Footloose multinationals?, CEPR Discussion Paper 3402.

Grubert, H. and J. Mutti (2000), Do taxes influence where U.S. corporations invest?, National Tax Journal, Vol. 53, pp. 825-839.

Haaland, J.I. and I. Wooton (1999), International Competition for Multinational Investment, Scandinavian Journal of Economics, Vol. 101, pp. 631-649.

Haaland, J.I. and I. Wooton (2002), Multinational investment, industry risk and policy competition, CEPR Discussion Paper 3152

Haaland, J.I., I. Wooton and G. Faggio (2002), Multinational firms: Easy come, easy go?, mimeo, Norwegian School of Economics and Business Administration.

Haufler, A. and I. Wooton (1999), Country size and tax competition for foreign direct investment, Journal of Public Economics, Vol. 71, pp. 121-139.

Head, K. (1998), Comment on 'Comparing Wages, Skills, and Productivity between Domestically and Foreign-Owned Manufacturing Establishments in the United States', in Baldwin, R., R. Lipsey and J.D. Richardson (eds.), Geography and Ownership as Bases for Economic Accounting, Chicago University Press, pp. 255-258.

Head, Keith C.; John C. Ries and Deborah L. Swenson (1999), Attracting Foreign Manufacturing: Investment Promotion and Agglomeration, Regional Science and Urban Economics, Vol. 29, pp. 197-218.

Hines, J.R. (1996), Altered states: Taxes and the location of foreign direct investment in America, American Economic Review, Vol. 86, pp. 1076-1094. 
Hubert, F. and N. Pain (2002), Fiscal incentives, European integration and the location of foreign direct investment, The Manchester School, Vol. 70, pp. 336-363.

Kind, H.J., K.H. Midelfart Knarvik and G. Schjelderup (2000), Competing for capital in a 'lumpy' world, Journal of Public Economics, Vol. 78, pp. 253-274.

Jackman, R., R. Layard and S. Nickell (1996), Combating unemployment: Is flexibility enough?, in Macroeconomic policies and structural reform, OECD, Paris.

Lazear, E. (1990), Job security provisions and employment, Quarterly Journal of Economics, Vol. 105, pp. 699-726.

Lipsey, R.E. (2002), Foreign direct investment and the operations of multinational firms: Concepts, history and data, NBER Working Paper 8665.

Markusen, J.R. (2002), Multinational firms and the theory of international trade. Cambridge, MA: MIT Press.

Mody, A., A. Razin and E. Sadka (2002), The role of information in driving FDI: Theory and evidence, NBER Working Paper 9255.

Oi, W.Y. (1962), Labor as a quasi-fixed factor, Journal of Political Economy, Vol. 70, pp. 538555.

Portes, R., H. Rey and Y. Oh (2001), Information and capital flows: The determinants of transactions in financial assets, European Economic Review, Vol. 45, pp. 783-796.

Schneider, F. and B.S. Frey (1985), Economic and political determinants of foreign direct investment, World Development, Vol. 13, pp. 161-175.

Tybout, M.J. and J.R. Tybout (1997), The decision to export in Colombia: An empirical model of entry with sunk costs, American Economic Review, Vol. 87, pp. 545-564.

Wei, S.-J. (2000), How taxing is corruption on international investors?, Review of Economics and Statistics, Vol. 82, pp. 1-11. 
Table 1: Mean values of firing cost index and effective tax rate by country (1986-1996)

\begin{tabular}{|c|c|c|c|c|}
\hline \multirow[b]{2}{*}{ Country } & \multicolumn{2}{|c|}{ Firing cost index } & \multicolumn{2}{|c|}{ Effective tax rate } \\
\hline & mean & std.dev. & mean & std.dev. \\
\hline AUSTRALIA & 0.473 & 0.136 & 0.323 & 0.044 \\
\hline AUSTRIA & 0.460 & 0.068 & 0.353 & 0.188 \\
\hline BLEU & 0.411 & 0.036 & 0.268 & 0.061 \\
\hline BRAZIL & 0.620 & 0.075 & 0.209 & 0.088 \\
\hline CANADA & 0.606 & 0.043 & 0.328 & 0.041 \\
\hline CHILE* $^{*}$ & 0.673 & 0.007 & 0.097 & 0.027 \\
\hline COLOMBIA $^{*}$ & 0.550 & 0.020 & 0.288 & 0.040 \\
\hline FINLAND & 0.475 & 0.025 & 0.231 & 0.087 \\
\hline FRANCE & 0.415 & 0.083 & 0.292 & 0.078 \\
\hline GERMANY & 0.425 & 0.042 & 0.320 & 0.090 \\
\hline GREECE & 0.377 & 0.072 & 0.282 & 0.045 \\
\hline HONG KONG & 0.830 & 0.058 & 0.107 & 0.021 \\
\hline INDIA & 0.279 & 0.062 & 0.362 & 0.056 \\
\hline INDONESIA $^{\#}$ & 0.508 & 0.088 & 0.309 & 0.035 \\
\hline IRELAND & 0.490 & 0.074 & 0.053 & 0.026 \\
\hline ITALY & 0.322 & 0.069 & 0.334 & 0.035 \\
\hline JAPAN & 0.560 & 0.028 & 0.499 & 0.047 \\
\hline KOREA & 0.508 & 0.076 & 0.307 & 0.085 \\
\hline MALAYSIA & 0.624 & 0.053 & 0.123 & 0.075 \\
\hline MEXICO & 0.505 & 0.031 & 0.266 & 0.068 \\
\hline NETHERLANDS & 0.381 & 0.046 & 0.236 & 0.069 \\
\hline NEW ZEALAND & 0.575 & 0.254 & 0.255 & 0.135 \\
\hline NORWAY & 0.463 & 0.054 & 0.228 & 0.086 \\
\hline PORTUGAL & 0.346 & 0.049 & 0.265 & 0.015 \\
\hline SINGAPORE & 0.758 & 0.088 & 0.048 & 0.013 \\
\hline SOUTH AFRICA $^{+}$ & 0.624 & 0.092 & 0.358 & 0.084 \\
\hline SPAIN & 0.307 & 0.039 & 0.236 & 0.035 \\
\hline SWEDEN & 0.414 & 0.053 & 0.287 & 0.195 \\
\hline SWITZERLAND & 0.698 & 0.098 & 0.135 & 0.032 \\
\hline THAILAND & 0.693 & 0.046 & 0.230 & 0.068 \\
\hline TURKEY & 0.598 & 0.122 & 0.373 & 0.085 \\
\hline UK & 0.673 & 0.108 & 0.254 & 0.063 \\
\hline VENEZUELA $^{+}$ & 0.465 & 0.056 & 0.226 & 0.090 \\
\hline US & 0.708 & 0.034 & & \\
\hline OVERALL MEAN & 0.510 & 0.155 & 0.248 & 0.123 \\
\hline
\end{tabular}

Notes: The table reports simple unweighted means

Means and std.devs. for firing cost index relate to * 1994-1996; + 1992-1996; \# 1988-1996 
Table 2: Changes in firing cost index and effective tax rate between 1986 and 1996 by country

\begin{tabular}{|c|c|c|c|c|}
\hline \multirow[b]{2}{*}{ Country } & \multicolumn{2}{|c|}{ Firing cost index } & \multicolumn{2}{|c|}{ Effective tax rate } \\
\hline & percentage & absolute & percentage & absolute \\
\hline AUSTRALIA & 0.760 & 0.200 & -0.161 & -0.060 \\
\hline AUSTRIA & 0.158 & 0.063 & 0.303 & 0.071 \\
\hline BLEU & -0.099 & -0.039 & -0.435 & -0.165 \\
\hline BRAZIL & 0.314 & 0.166 & -0.531 & -0.154 \\
\hline CANADA & 0.105 & 0.058 & -0.230 & -0.088 \\
\hline CHILE* & -0.017 & -0.012 & 0.012 & 0.001 \\
\hline COLOMBIA $^{*}$ & 0.052 & 0.028 & -0.332 & -0.117 \\
\hline FINLAND & -0.028 & -0.013 & -0.475 & -0.169 \\
\hline FRANCE & 0.499 & 0.136 & -0.423 & -0.167 \\
\hline GERMANY & 0.095 & 0.036 & -0.376 & -0.180 \\
\hline GREECE & 0.554 & 0.154 & 0.455 & 0.102 \\
\hline HONG KONG & 0.166 & 0.127 & 0.219 & 0.021 \\
\hline INDIA & -0.429 & -0.150 & -0.268 & -0.108 \\
\hline INDONESIA $^{\#}$ & 0.633 & 0.229 & -0.151 & -0.053 \\
\hline IRELAND & 0.436 & 0.157 & 1.266 & 0.043 \\
\hline ITALY & -0.174 & -0.059 & -0.017 & -0.006 \\
\hline JAPAN & 0.087 & 0.047 & -0.100 & -0.050 \\
\hline KOREA & -0.134 & -0.079 & -0.233 & -0.063 \\
\hline MALAYSIA & 0.054 & 0.031 & -0.748 & -0.200 \\
\hline MEXICO & -0.038 & -0.021 & -0.487 & -0.147 \\
\hline NETHERLANDS & 0.037 & 0.013 & -0.523 & -0.177 \\
\hline NEW ZEALAND & 1.693 & 0.445 & -0.758 & -0.332 \\
\hline NORWAY & 0.175 & 0.070 & -0.523 & -0.189 \\
\hline PORTUGAL & 0.496 & 0.134 & 0.132 & 0.032 \\
\hline SINGAPORE & 0.305 & 0.198 & 1.109 & 0.028 \\
\hline SOUTH AFRICA $^{+}$ & -0.242 & -0.166 & -0.219 & -0.063 \\
\hline SPAIN & 0.014 & 0.004 & -0.252 & -0.070 \\
\hline SWEDEN & 0.129 & 0.044 & -0.771 & -0.428 \\
\hline SWITZERLAND & 0.304 & 0.182 & -0.321 & -0.059 \\
\hline THAILAND & 0.094 & 0.059 & -0.185 & -0.052 \\
\hline TURKEY & 0.397 & 0.203 & 0.016 & 0.007 \\
\hline UK & 0.490 & 0.240 & -0.339 & -0.126 \\
\hline VENEZUELA $^{+}$ & -0.177 & -0.094 & -0.541 & -0.162 \\
\hline US & -0.041 & -0.028 & & \\
\hline OVERALL MEAN & 0.142 & 0.065 & -0.288 & -0.086 \\
\hline
\end{tabular}

Notes: The table reports simple unweighted means

Growth rates for firing cost index relate to * 1994-1996; + 1992-1996; \# 1988-1996 
Table 3: Regression results for full sample

\begin{tabular}{cccc}
\hline & $(1)$ & $(2)$ & $(3)$ \\
\hline exit cost index & total FDI & manufacturing FDI & services FDI \\
& 0.789 & 1.246 & -0.492 \\
effective tax rate & $(0.250)^{* *}$ & $(0.377)^{* *}$ & $(0.408)$ \\
GDP & -0.807 & -1.341 & -0.769 \\
& $(0.267)^{* *}$ & $(0.408)^{* *}$ & $(0.476)$ \\
GDP per capita & 0.686 & 0.966 & 0.718 \\
& $(0.103)^{* *}$ & $(0.133)^{* *}$ & $(0.132)^{* *}$ \\
distance & 0.264 & 0.125 & 0.598 \\
& $(0.103)^{*}$ & $(0.130)$ & $(0.130)^{* *}$ \\
English speaking & -0.463 & -0.672 & -0.196 \\
& $(0.207)^{*}$ & $(0.254)^{* *}$ & $(0.244)$ \\
Constant & 0.821 & 1.066 & 1.486 \\
& $(0.322)^{*}$ & $(0.394)^{* *}$ & $(0.413)^{* *}$ \\
Observations & 0.000 & 1.571 & 0.000 \\
units & $(0.000)$ & $(3.100)$ & $(0.000)$ \\
R-squared & 180 & 179 & 133 \\
Wald $(\lambda=0)$ & 33 & 33 & 30 \\
LM $(\mu=0)$ & 0.65 & 0.67 & 0.73 \\
Hausman $(\mathrm{p}$-value $)$ & $5498.00^{* *}$ & $284.73 * *$ & $3195.27 * *$ \\
& $224.61 * *$ & $234.75 * *$ & $123.79 * *$ \\
& 0.99 & 0.59 & 0.96 \\
\hline
\end{tabular}

Notes:

standard errors in parentheses

$*$ significant at $5 \%$;* significant at $1 \%$ time dummies included

Wald $(\lambda=0)$ test for joint significance of coefficients

$\operatorname{LM}(\mu=0)$ test for joint significance of country specific effects

Hausman test for RE specification 
Table 4: Interaction terms

\begin{tabular}{|c|c|c|c|c|c|c|}
\hline & $(1)$ & (2) & (3) & (4) & $(5)$ & $(6)$ \\
\hline & \multicolumn{3}{|c|}{ low income dummy } & \multicolumn{3}{|c|}{ low and middle income dummy } \\
\hline & total FDI & $\begin{array}{l}\text { manufactur } \\
\text { ing FDI }\end{array}$ & $\begin{array}{l}\text { services } \\
\text { FDI }\end{array}$ & total FDI & $\begin{array}{l}\text { manufactur } \\
\text { ing FDI }\end{array}$ & $\begin{array}{l}\text { services } \\
\text { FDI }\end{array}$ \\
\hline \multirow[t]{2}{*}{ exit cost index } & 0.880 & 1.053 & -0.347 & 0.778 & 0.927 & -0.477 \\
\hline & $(0.261)^{* *}$ & $(0.392)^{* *}$ & $(0.406)$ & $(0.288)^{* *}$ & $(0.436)^{*}$ & $(0.482)$ \\
\hline \multirow{2}{*}{$\begin{array}{c}\text { exit cost index } * \\
\text { developing dummy }\end{array}$} & -1.188 & 1.368 & 1.823 & -0.071 & 1.017 & -0.164 \\
\hline & $(1.049)$ & $(1.569)$ & $(1.623)$ & $(0.492)$ & $(0.744)$ & $(0.812)$ \\
\hline \multirow[t]{2}{*}{ effective tax rate } & -0.806 & -1.389 & -0.579 & -0.884 & -1.519 & -0.388 \\
\hline & $(0.270)^{* *}$ & $(0.410)^{* *}$ & $(0.451)$ & $(0.318)^{* *}$ & $(0.487)^{* *}$ & $(0.551)$ \\
\hline \multirow{2}{*}{$\begin{array}{l}\text { effective tax rate } * \\
\text { developing dummy }\end{array}$} & 0.425 & 2.900 & -12.126 & 0.522 & 0.644 & -1.140 \\
\hline & $(1.652)$ & $(2.503)$ & $(3.168)^{* *}$ & $(0.541)$ & $(0.825)$ & $(0.914)$ \\
\hline \multirow[t]{2}{*}{ GDP } & 0.660 & 1.036 & 0.691 & 0.686 & 0.961 & 0.702 \\
\hline & $(0.110)^{* *}$ & $(0.138)^{* *}$ & $(0.137)^{* *}$ & $(0.105)^{* *}$ & $(0.136)^{* *}$ & $(0.139)^{* *}$ \\
\hline \multirow[t]{2}{*}{ GDP per capita } & 0.336 & -0.048 & 0.614 & 0.108 & -0.025 & 0.574 \\
\hline & $(0.131)^{*}$ & $(0.166)$ & $(0.172)^{* *}$ & $(0.149)$ & $(0.199)$ & $(0.204)^{* *}$ \\
\hline \multirow[t]{2}{*}{ distance } & -0.505 & -0.558 & -0.248 & -0.471 & -0.694 & -0.189 \\
\hline & $(0.218)^{*}$ & $(0.262)^{*}$ & $(0.255)$ & $(0.210)^{*}$ & $(0.257)^{* *}$ & $(0.258)$ \\
\hline \multirow[t]{2}{*}{ English speaking } & 0.816 & 1.079 & 1.462 & 0.683 & 0.945 & 1.463 \\
\hline & $(0.328)^{*}$ & $(0.393)^{* *}$ & $(0.414)^{* *}$ & $(0.336)^{*}$ & $(0.412)^{*}$ & $(0.469)^{* *}$ \\
\hline \multirow[t]{2}{*}{ developing dummy } & 0.878 & -2.864 & 3.518 & -0.698 & -1.223 & 0.282 \\
\hline & $(0.920)$ & $(1.257)^{*}$ & $(1.210)^{* *}$ & $(0.483)$ & $(0.670)$ & $(0.724)$ \\
\hline \multirow[t]{2}{*}{ Constant } & 0.000 & -0.910 & 0.000 & 0.000 & 0.000 & 0.000 \\
\hline & $(0.000)$ & $(3.430)$ & $(0.000)$ & $(0.000)$ & $(0.000)$ & $(0.000)$ \\
\hline Observations & 180 & 179 & 133 & 180 & 179 & 133 \\
\hline units & 33 & 33 & 30 & 33 & 33 & 30 \\
\hline R-squared & 0.65 & 0.69 & 0.74 & 0.66 & 0.68 & 0.72 \\
\hline Wald $(\lambda=0)$ & $5306.81 * *$ & $293.56 * *$ & $3275.30 * *$ & $5397.93 * *$ & $2804.86^{* *}$ & $2920.92 * *$ \\
\hline $\operatorname{LM}(\mu=0)$ & $194.69 * *$ & $222.97 * *$ & $124.82 * *$ & $223.07 * *$ & $216.62 * *$ & $118.09 * *$ \\
\hline Hausman ( $p$-value) & 1.00 & 0.99 & 0.98 & 0.99 & 0.79 & 0.00 \\
\hline Wald (interaction) & 1.82 & 5.21 & $16.20 * *$ & 3.87 & 3.47 & 1.57 \\
\hline
\end{tabular}

Notes:

standard errors in parentheses

$*$ significant at $5 \% ; * *$ significant at $1 \%$

time dummies included

Wald $(\lambda=0)$ test for joint significance of coefficients

LM $(\mu=0)$ test for joint significance of country specific effects

Wald (interaction) test for joint significance of interaction terms and developing dummy

Hausman test for RE specification 
Table 5: Robustness check - constrained model

\begin{tabular}{cccc}
\hline & $(1)$ & $(2)$ & $(3)$ \\
\hline exit cost index & total FDI & manufacturing FDI & services FDI \\
& 0.883 & 1.261 & -0.570 \\
effective tax rate & $(0.253)^{* *}$ & $(0.398)^{* *}$ & $(0.400)$ \\
& -0.762 & -1.259 & -0.808 \\
GDP & $(0.269)^{* *}$ & $(0.431)^{* *}$ & $(0.460)$ \\
& 0.736 & 1.006 & 0.745 \\
GDP per capita & $(0.108)^{* *}$ & $(0.146)^{* *}$ & $(0.139)^{* *}$ \\
& 0.335 & 0.046 & 0.712 \\
distance & $(0.113)^{* * *}$ & $(0.151)$ & $(0.145)^{* *}$ \\
& -0.358 & -0.447 & -0.107 \\
English speaking & $(0.233)$ & $(0.300)$ & $(0.278)$ \\
& 1.260 & 1.397 & 1.577 \\
Constant & $(0.358)^{* * *}$ & $(0.458)^{* *}$ & $(0.430)^{* *}$ \\
& 0.000 & 0.000 & 0.000 \\
Observations & $(0.000)$ & $(0.000)$ & $(0.000)$ \\
units & 165 & 164 & 123 \\
R-squared & 28 & 28 & 27 \\
Wald $(\lambda=0)$ & 0.71 & 0.66 & 0.72 \\
LM $(\mu=0)$ & $4917.13 * *$ & $2383.54 * *$ & $2882.33^{* *}$ \\
Hausman $(\mathrm{p}-\mathrm{value})$ & $211.06^{* *}$ & $217.02 * *$ & $114.33 * *$ \\
\hline & 0.99 & 0.88 & 0.99 \\
\hline
\end{tabular}

Notes:

standard errors in parentheses

$*$ significant at $5 \%$;* significant at $1 \%$ time dummies included

Wald $(\lambda=0)$ test for joint significance of coefficients

$\operatorname{LM}(\mu=0)$ test for joint significance of country specific effects

Hausman test for RE specification 
Table 6: Robustness check - interaction terms

\begin{tabular}{|c|c|c|c|c|c|c|}
\hline & $(1)$ & $(2)$ & (3) & (4) & $(5)$ & $(6)$ \\
\hline & \multicolumn{3}{|c|}{ low income dummy } & \multicolumn{3}{|c|}{ low and middle income dummy } \\
\hline & total FDI & $\begin{array}{l}\text { manufactur } \\
\text { ing FDI }\end{array}$ & $\begin{array}{l}\text { services } \\
\text { FDI }\end{array}$ & total FDI & $\begin{array}{l}\text { manufactur } \\
\text { ing FDI }\end{array}$ & $\begin{array}{l}\text { services } \\
\text { FDI }\end{array}$ \\
\hline \multirow[t]{2}{*}{ exit cost index } & 0.876 & 0.929 & -0.269 & 0.734 & 0.864 & -0.588 \\
\hline & $(0.264)^{* *}$ & $(0.405)^{*}$ & $(0.374)$ & $(0.281)^{* *}$ & $(0.448)$ & $(0.461)$ \\
\hline \multirow{2}{*}{$\begin{array}{c}\text { exit cost index } * \\
\text { developing dummy }\end{array}$} & -0.827 & 5.696 & 31.602 & 0.443 & 1.513 & -0.146 \\
\hline & $(1.695)$ & $(2.646)^{*}$ & $(26.904)$ & $(0.531)$ & $(0.842)$ & $(0.851)$ \\
\hline \multirow[t]{2}{*}{ effective tax rate } & -0.759 & -1.254 & -0.611 & -1.010 & -1.547 & -0.499 \\
\hline & $(0.273)^{* *}$ & $(0.425)^{* *}$ & $(0.411)$ & $(0.311)^{* *}$ & $(0.503)^{* *}$ & $(0.525)$ \\
\hline \multirow{2}{*}{$\begin{array}{l}\text { effective tax rate } * \\
\text { developing dummy }\end{array}$} & 0.912 & 3.488 & -56.749 & 1.064 & 1.103 & -0.952 \\
\hline & (1.819) & $(2.842)$ & $(36.138)$ & $(0.572)$ & $(0.920)$ & $(0.915)$ \\
\hline \multirow[t]{2}{*}{ GDP } & 0.757 & 1.077 & 0.711 & 0.767 & 1.029 & 0.727 \\
\hline & $(0.113)^{* *}$ & $(0.148)^{* *}$ & $(0.143)^{* *}$ & $(0.111)^{* *}$ & $(0.148)^{* *}$ & $(0.147)^{* *}$ \\
\hline \multirow[t]{2}{*}{ GDP per capita } & 0.272 & -0.116 & 0.710 & 0.277 & -0.029 & 0.689 \\
\hline & $(0.143)$ & $(0.190)$ & $(0.184)^{* *}$ & $(0.159)$ & $(0.221)$ & $(0.219)^{* *}$ \\
\hline \multirow[t]{2}{*}{ distance } & -0.336 & -0.367 & -0.137 & -0.335 & -0.436 & -0.109 \\
\hline & $(0.240)$ & $(0.299)$ & $(0.285)$ & $(0.242)$ & $(0.302)$ & $(0.297)$ \\
\hline \multirow[t]{2}{*}{ English speaking } & 1.269 & 1.459 & 1.533 & 1.178 & 1.324 & 1.554 \\
\hline & $(0.366)^{* *}$ & $(0.454)^{* *}$ & $(0.438)^{* *}$ & $(0.392)^{* *}$ & $(0.491)^{* *}$ & $(0.490)^{* *}$ \\
\hline \multirow[t]{2}{*}{ developing dummy } & -0.791 & -4.527 & 11.308 & -0.836 & -1.403 & 0.237 \\
\hline & (1.169) & $(1.630)^{* *}$ & $(5.486)^{*}$ & $(0.513)$ & $(0.736)$ & $(0.740)$ \\
\hline \multirow[t]{2}{*}{ Constant } & 3.287 & 0.000 & 0.000 & 3.406 & 0.000 & 0.000 \\
\hline & (3.039) & $(0.000)$ & $(0.000)$ & $(2.929)$ & $(0.000)$ & $(0.000)$ \\
\hline Observations & 165 & 164 & 123 & 165 & 164 & 123 \\
\hline units & 28 & 28 & 27 & 28 & 28 & 27 \\
\hline R-squared & 0.71 & 0.68 & 0.73 & 0.71 & 0.68 & 0.71 \\
\hline Wald $(\lambda=0)$ & $479.93 * *$ & $2447.70 * *$ & $2913.46 * *$ & $497.72 * *$ & $2368.99 * *$ & $2574.16^{* *}$ \\
\hline $\operatorname{LM}(\mu=0)$ & $212.62 * *$ & $211.70 * *$ & $126.39 * *$ & $206.26^{* *}$ & $203.11 * *$ & $109.39 * *$ \\
\hline Hausman (p-value) & 0.00 & 0.98 & 0.99 & 1.00 & 0.85 & 0.96 \\
\hline Wald (interaction) & 1.02 & $9.43 *$ & $23.63 * *$ & 4.77 & 4.5 & 1.11 \\
\hline
\end{tabular}

Notes:

standard errors in parentheses

$*$ significant at $5 \%$;* significant at $1 \%$

time dummies included

Wald $(\lambda=0)$ test for joint significance of coefficients

$\operatorname{LM}(\mu=0)$ test for joint significance of country specific effects

Wald (interaction) test for joint significance of interaction terms and developing dummy

Hausman test for RE specification 
Figure 1
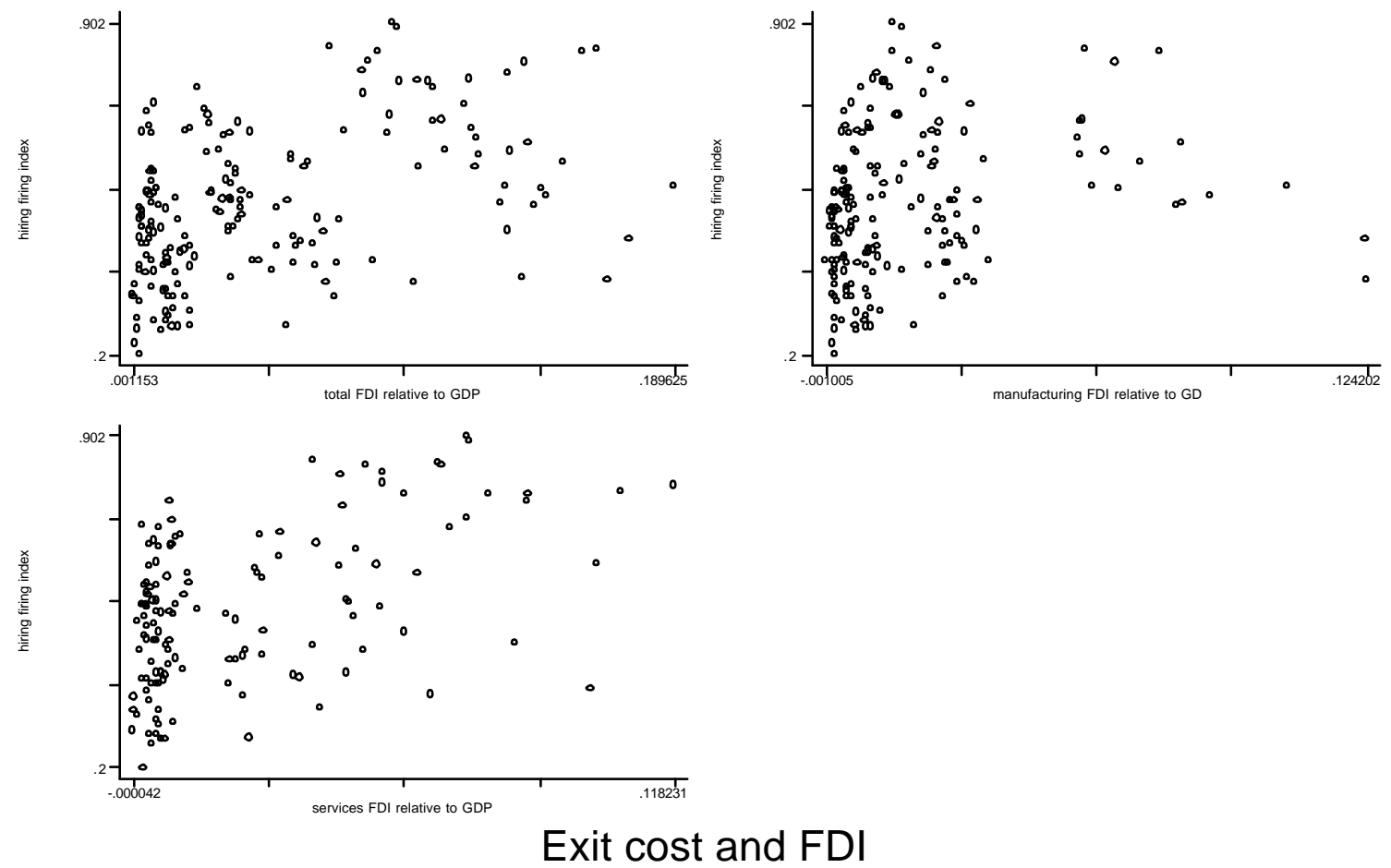

Figure 2
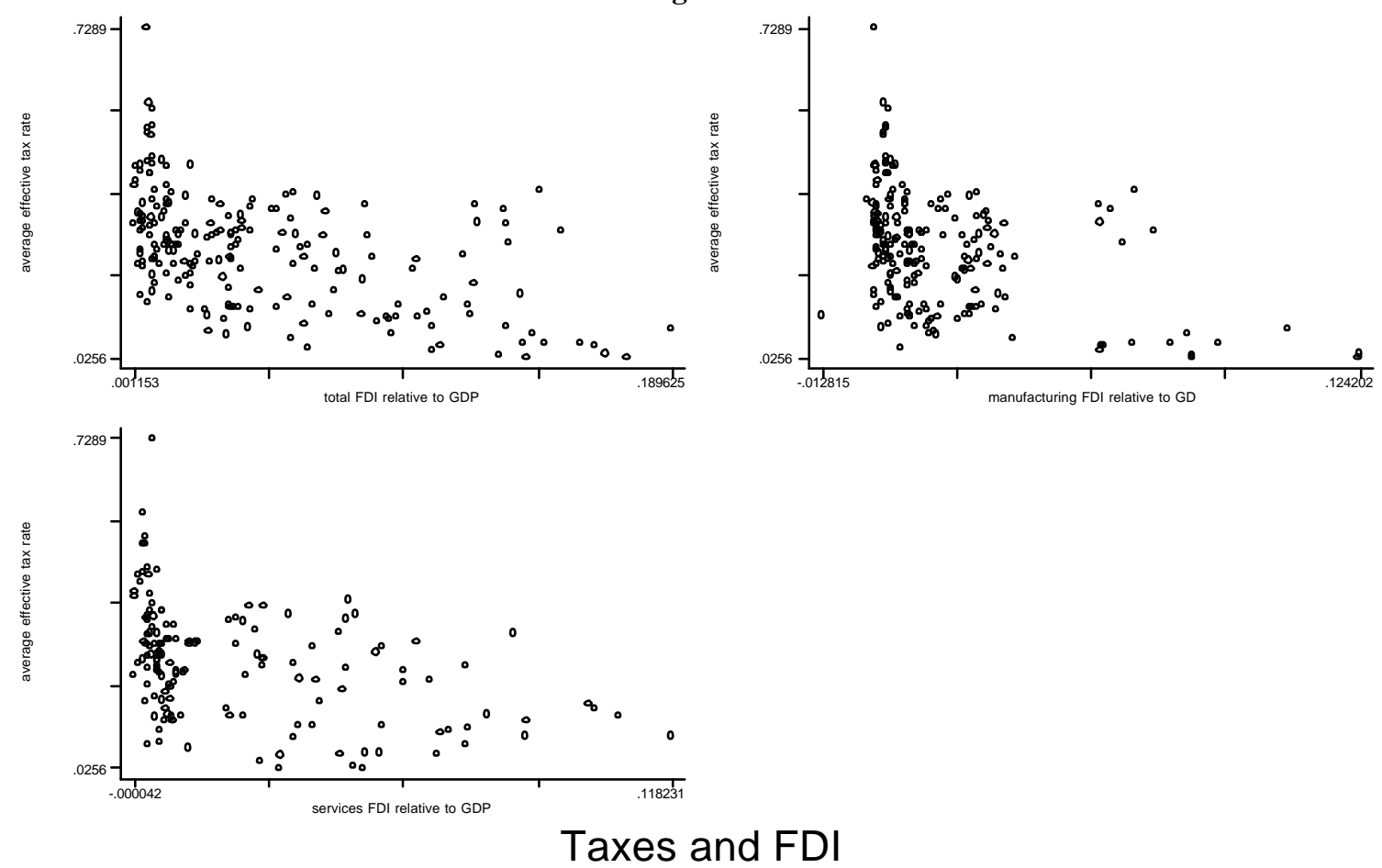


\section{IZA Discussion Papers}

\begin{tabular}{|c|c|c|c|c|}
\hline No. & Author(s) & Title & Area & Date \\
\hline 649 & $\begin{array}{l}\text { J. van Ours } \\
\text { J. Veenman }\end{array}$ & $\begin{array}{l}\text { From Parent to Child: Early Labor Market } \\
\text { Experiences of Second-Generation Immigrants } \\
\text { in the Netherlands }\end{array}$ & 1 & $11 / 02$ \\
\hline 650 & $\begin{array}{l}\text { H. Battu } \\
\text { P. J. Sloane }\end{array}$ & Overeducation and Ethnic Minorities in Britain & 2 & $11 / 02$ \\
\hline 651 & E. Schlicht & $\begin{array}{l}\text { Social Evolution, Corporate Culture, and } \\
\text { Exploitation }\end{array}$ & 3 & $11 / 02$ \\
\hline 652 & E. Plug & $\begin{array}{l}\text { How Do Parents Raise the Educational } \\
\text { Attainment of Future Generations? }\end{array}$ & 5 & $11 / 02$ \\
\hline 653 & $\begin{array}{l}\text { W. Groot } \\
\text { E. Plug } \\
\text { H. Maassen van den } \\
\text { Brink }\end{array}$ & $\begin{array}{l}\text { Money for Health: The Compensating Variation } \\
\text { of Cardiovascular Diseases }\end{array}$ & 6 & $11 / 02$ \\
\hline 654 & $\begin{array}{l}\text { C. Ruhm } \\
\text { U. G. Gerdtham }\end{array}$ & $\begin{array}{l}\text { Deaths Rise in Good Economic Times: Evidence } \\
\text { From the OECD }\end{array}$ & 2 & $11 / 02$ \\
\hline 655 & $\begin{array}{l}\text { W. Arulampalam } \\
\text { R. A. Naylor } \\
\text { J. P. Smith }\end{array}$ & $\begin{array}{l}\text { Effects of In-Class Variation and Student Rank } \\
\text { on the Probability of Withdrawal: Cross-Section } \\
\text { and Time-Series Analysis for UK University } \\
\text { Students }\end{array}$ & 2 & $11 / 02$ \\
\hline 656 & $\begin{array}{l}\text { T. Beissinger } \\
\text { O. Büsse }\end{array}$ & $\begin{array}{l}\text { The Impact of the Unemployment Benefit } \\
\text { System on International Spillover Effects }\end{array}$ & 2 & $11 / 02$ \\
\hline 657 & $\begin{array}{l}\text { A. Kugler } \\
\text { J. F. Jimeno } \\
\text { V. Hernanz }\end{array}$ & $\begin{array}{l}\text { Employment Consequences of Restrictive } \\
\text { Permanent Contracts: Evidence from Spanish } \\
\text { Labor Market Reforms }\end{array}$ & 2 & $11 / 02$ \\
\hline 658 & $\begin{array}{l}\text { G. Brunello } \\
\text { R. Winter-Ebmer }\end{array}$ & $\begin{array}{l}\text { Why Do Students Expect to Stay Longer in } \\
\text { College? Evidence from Europe }\end{array}$ & 5 & $12 / 02$ \\
\hline 659 & $\begin{array}{l}\text { D. Byrne } \\
\text { E. Strobl }\end{array}$ & $\begin{array}{l}\text { Defining Unemployment in Developing } \\
\text { Countries: Evidence from Trinidad and Tobago }\end{array}$ & 4 & $12 / 02$ \\
\hline 660 & $\begin{array}{l}\text { E. Strobl } \\
\text { R. Thornton }\end{array}$ & $\begin{array}{l}\text { Do Large Employers Pay More in Developing } \\
\text { Countries? The Case of Five African Countries }\end{array}$ & 4 & $12 / 02$ \\
\hline 661 & $\begin{array}{l}\text { E. Strobl } \\
\text { F. Walsh }\end{array}$ & $\begin{array}{l}\text { Efficiency Wages and Effort: Are Hard Jobs } \\
\text { Better? }\end{array}$ & 3 & $12 / 02$ \\
\hline 662 & $\begin{array}{l}\text { E. Strobl } \\
\text { F. Walsh }\end{array}$ & $\begin{array}{l}\text { Getting It Right: Employment Subsidy or } \\
\text { Minimum Wage? }\end{array}$ & 3 & $12 / 02$ \\
\hline 663 & $\begin{array}{l}\text { A. B. Krueger } \\
\text { P. Zhu }\end{array}$ & $\begin{array}{l}\text { Another Look at the New York City School } \\
\text { Voucher Experiment }\end{array}$ & 6 & $12 / 02$ \\
\hline 664 & $\begin{array}{l}\text { J. R. Skaksen } \\
\text { A. Sørensen }\end{array}$ & $\begin{array}{l}\text { Skill Upgrading and Rigid Relative Wages: The } \\
\text { Case of Danish Manufacturing }\end{array}$ & 2 & $12 / 02$ \\
\hline 665 & H. Görg & $\begin{array}{l}\text { Fancy a Stay at the "Hotel California"? Foreign } \\
\text { Direct Investment, Taxation and Firing Costs }\end{array}$ & 2 & $12 / 02$ \\
\hline
\end{tabular}

An updated list of IZA Discussion Papers is available on the center's homepage www.iza.org. 